\title{
Ampule Dosing Unit
}

National Cancer Institute

\section{Source}

National Cancer Institute. Ampule Dosing Unit. NCI Thesaurus. Code C48473.

A dosing unit equal to the amount of active ing redient(s) contained in an ampule. 